\title{
Studying of the resistance to winter stresses of grapevine varieties of different ecological and geographical origin*
}

\author{
Nataliya Nenko $^{1 * *}$, Irina Ilina $^{1}$, Natalia Zaporozhets ${ }^{1}$, Galina Kiseleva ${ }^{1}$, and Tatiana \\ Skhalyakho ${ }^{1}$ \\ ${ }^{1}$ Federal State Budget Scientific Institution «North Caucasian Regional Research Institute of \\ Horticulture, Viticulture, Wine-making», 40 - Years of Victory, 39, Krasnodar, 350901, Russia
}

\begin{abstract}
In terms of climate change researches about adaptation mechanism of perennial crop plant to summer and winter stresses are actual. Physiological-biochemical assessment of grapevine varieties allows to clarify the mechanisms of protective and adaptive reaction on stresses and identify perspective genotypes for cultivation in stressful terms. Ecological and geographical origin are important in this case. Winterhardiness of following grapevine varieties: 'Kristal', 'Aligote', 'Dostoyniy' 'Krasnostop AZOS', 'Zarif' and 'Vostorg', are studied in conditions of Anapa-Taman region of the Russian Federation. At the beginning of winter reduced water content of vine tissue are noted for 'Kristal', 'Krasnostop AZOS' and 'Dostoyniy' (41,4-45,3\%). Also, for this varieties are found elevated accumulation of sucrose ( 2 times more) which means high resistance to low temperature. Intensification of antioxidative protective system's functioning in response on stress are discovered for varieties 'Kristal', 'Krasnostop AZOS', 'Dostoyniy' and 'Vostorg'. High containing of anthocyanins and chalcones in varieties 'Kristal', 'Dostoyniy', 'Krasnostop AZOS' and ascorbic acid in varieties 'Krasnostop AZOS', 'Dostoyniy' are revealed. According to generalized assessment of physiological-biochemical research results in conditions of climate change in Anapa-Taman region of Russia more winterhardiness were varieties 'Krasnostop AZOS', 'Dostoyniy', 'Kristal' than varieties 'Aligote', 'Vostorg', 'Zarif'.
\end{abstract}

\section{Introduction}

Develop of freeze resistance in autumn during process of hardening and its stability during cold wave in thawing weather are very important for grape wintering [1,2]. Analysis of climatic change in Anapa-Taman region of the Russian Federation showed increase of lowtemperature stresses frequency in period of hardening with extension of warm autumn period, increase of frost frequency under $-15^{\circ} \mathrm{C}$ in the same period and large amplitude of

\footnotetext{
* The reported study was funded by RFBR and Krasnodar Territory Administration according to the research project № 19-44-230021 r_a

** Corresponding author: nenko.nataliya@yandex.ru
} 
temperature in winter season. Due to previously mentioned climatic change complex of adaptative reaction to new environ conditions for some varieties was changed. Hardening was deficiently and resistance to winter stresses was decreased. Therefore, researches about physiological-biochemical adaptation mechanism of grapevine varieties to winter stresses in climatic changes conditions are actual.

At this time searching of diagnostic criteria of resistance to stressful environ conditions are persisted for the purpose of effective and quick selection of grapevine varieties and usage adaptive to abiotic stresses varieties [3,4].

The object of the research was physiological-biochemical assessment of grapevine varieties of different ecological and geographical origin under stressful conditions of winter and selection perspective genotypes for cultivation.

\section{Materials and Methods}

Research was carried out in the period 2017-2019. on the basis of the ampelographic collection of the North Caucasian Federal Scientific Centre of Horticulture, Viticulture, Winemaking, located in Anapa. The study involved following groups by origin of grapevine: interspecific hybrids of grapes of Euro-Amur-American origin ('Kristal' - control sample); conv. occidientalis Negr. ('Aligote'); Euro-American origin ('Dostoyniy' and 'Krasnostop AZOS'); conv. orientalis Negr. ('Zarif'), Amur-Euro-American origin ('Vostorg'). The water content of vine tissues and biochemical indicators which most fully characterize the frost resistance of grapes according to the results of our studies [5.6] (the content of proline, sucrose, ascorbic acid, anthocyanins and chalkones) were determined for the physiologicalbiochemical assessment of grapevine varieties.

Monitoring of weather conditions 2017-2019 showed an increase in the minimum air temperature in December from $-9{ }^{\circ} \mathrm{C}$ to $-1{ }^{\circ} \mathrm{C}$, in January - from $-13{ }^{\circ} \mathrm{C}$ to $-3{ }^{\circ} \mathrm{C}$, in February - from -11 to $-5^{\circ} \mathrm{C}$. The maximum air temperature increased in December from $+12^{\circ} \mathrm{C}$ to $+14{ }^{\circ} \mathrm{C}$, in January and February it reached from +14 to $+15^{\circ} \mathrm{C}$. At the same time, the temperature amplitude decreased in December by $10^{\circ} \mathrm{C}$, in January - by $12{ }^{\circ} \mathrm{C}$, in February - by $3{ }^{\circ} \mathrm{C}$.

Low temperature resistance of grapevines depends on external conditions, physiological state of plants, direction and nature of metabolism in its tissues [2,7]. Winterhardiness mostly depends on the degree of maturation of the tissues and their water content by the beginning of winter rest. With complete maturation of tissues, a clear border between woody tissue and cambium is indicated.

\section{Results and Discussion}

One of the indexes of increasing resistance of grapevine varieties to low temperature during winter dormancy is a decrease in the water content of tissues [8]. The total water content in the vines of some grape varieties under various cultivation conditions by the beginning of winter was on average $50 \%$ [9].

In our research reduced water content of vine tissues are noted for 'Kristal', 'Krasnostop AZOS' and 'Dostoyniy' (41,4-45,3 \%), for other varieties it was 51,2-56,4 \%. In January and February there was a slight increase in the water content with the same variability of the index between varieties (fig. 1). 


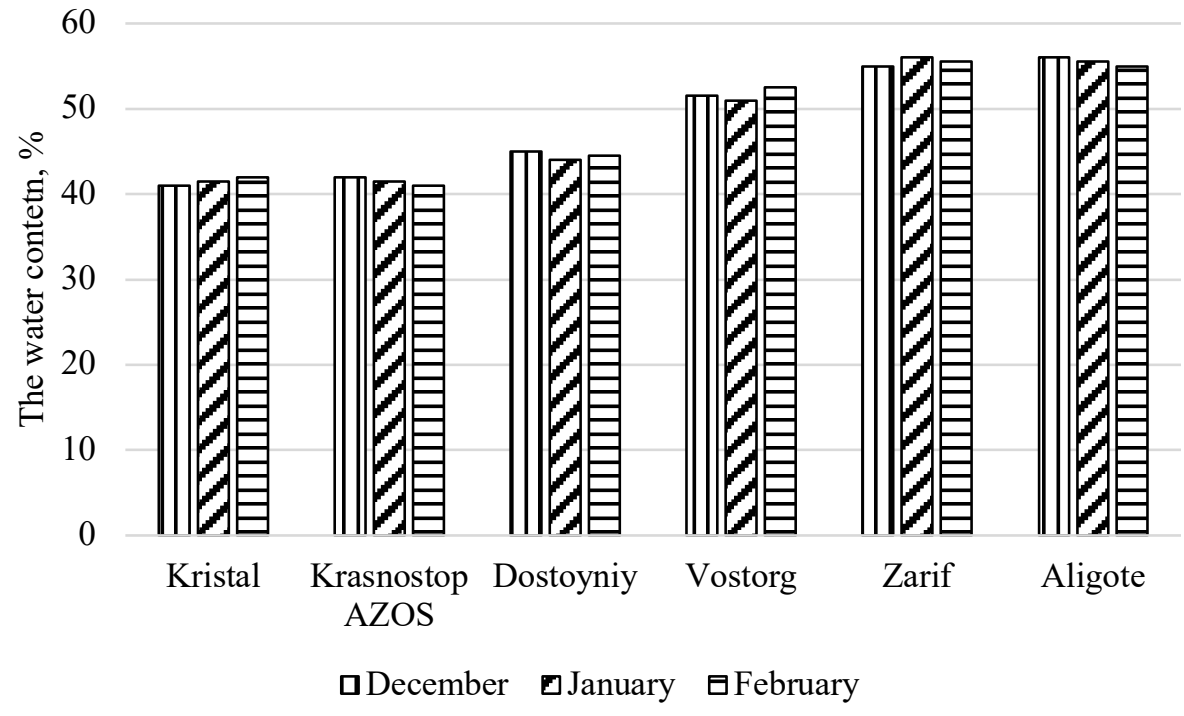

Fig. 1. Dynamic of water content of vine tissue in winter season 2017-2019 (average value) LSD $_{0,5}$ : December-0,16; January- 0,15; February- 0,19

Constitutive stability to reduced temperatures of vegetating plants is quite low. Frost resistance is formed under conditions of low temperatures during hardening. At the time of preparation for winter dormancy during hardening, intensive hydrolysis of starch occurs with the formation of sugars, which are protective substances. It is a common fact that increasing the sugar content boosts the osmotic pressure in the plant cell, protecting intracellular water from freezing. Frost-resistant grape varieties are distinguished by the fact that when exposed to low-temperature stresses, starch is hydrolyzed in the cytoplasm to form di and monosaccharides [10].

We have identified that the content of sucrose in hibernating bud in the varieties 'Dostoyniy', 'Krasnostop AZOS', 'Kristal' was 2 times more than in other studied varieties, indicating their advanced resistance to low temperatures (Fig. 2).

The protective function in plant resistance to low temperatures is performed by anthocyanins, which are a thermo-accumulating light-protective barrier, and chalcones, that have high antioxidant activity $[11,12]$. 


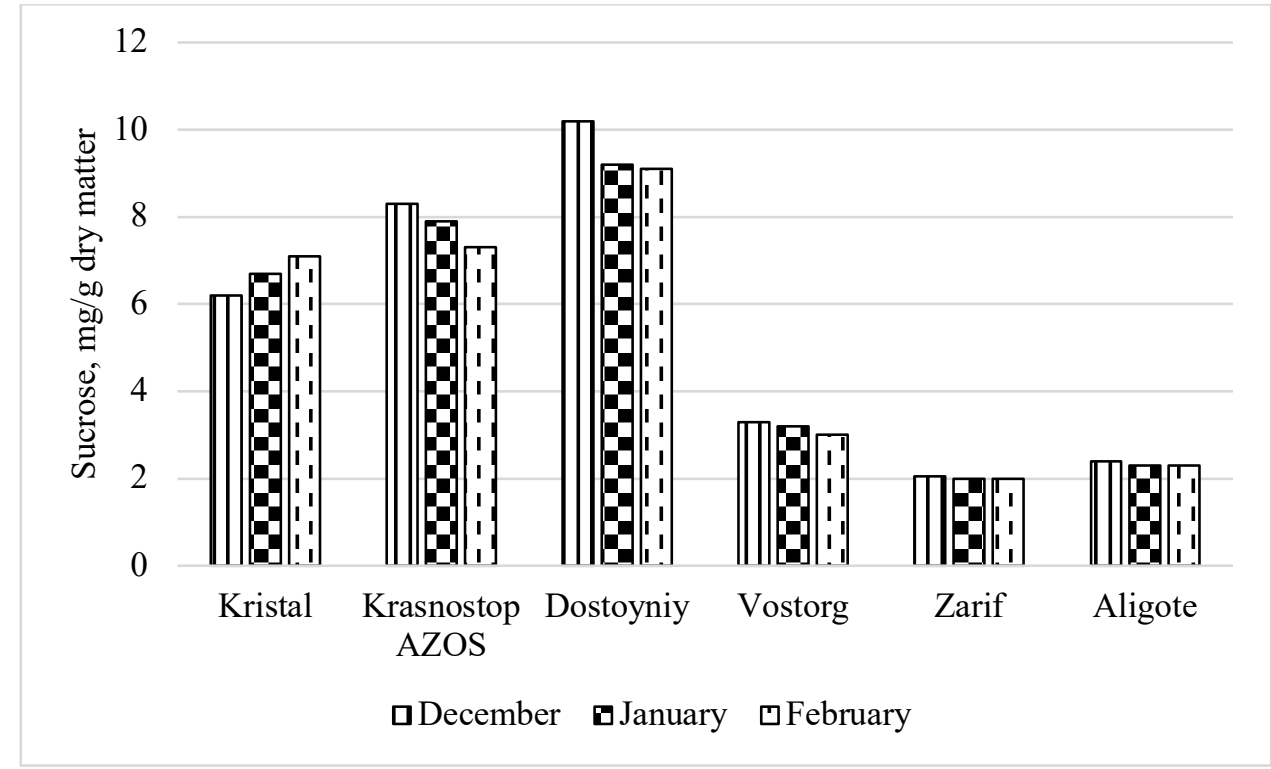

Fig. 2. Dynamic of sucrose contained in grape buds in winter season 2017-2019 (average value) $\mathrm{LSD}_{0,5}$ : December - 0,26; January-0,95; February- 0,21

As a result of the study of the metabolism of phenolic compounds, an advanced content of anthocyanins and chalcones was found in the varieties 'Kristal', 'Dostoyniy', 'Krasnostop AZOS' (in 1.8 times) (Fig. 3).

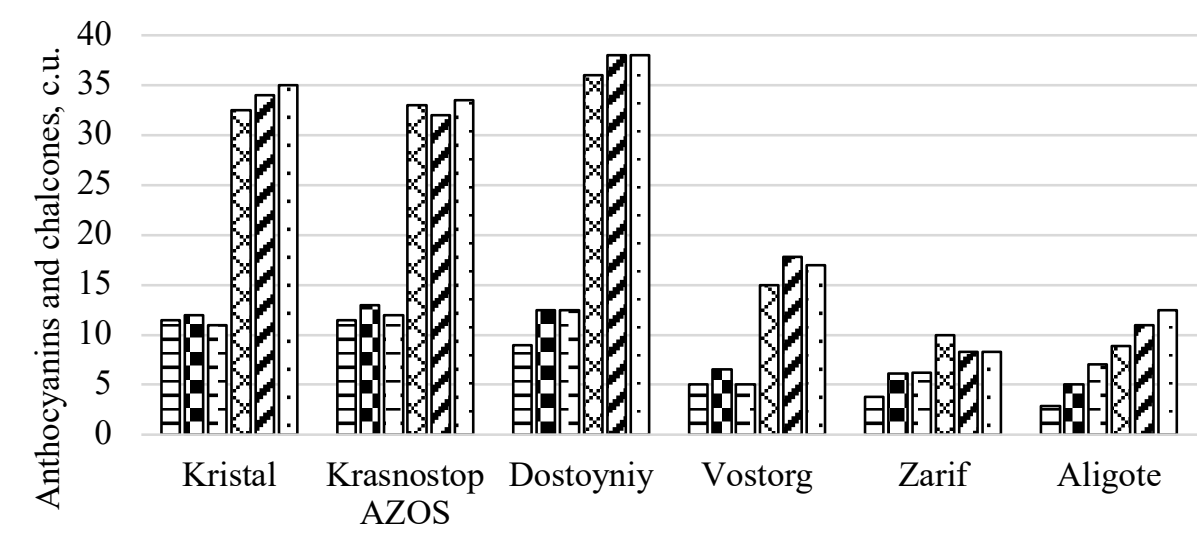

$\square$ Anthocyanins December $\square$ Anthocyanins January

$\square$ Anthocyanins Febrary $\square$ Chalcones December

$\square$ Chalcones January $\quad \square$ Chalcones February

Fig. 3. Anthocyanins and chalcones contained in grape cortex in winter season 2017-2019 (average value) $\mathrm{LSD}_{0,5}$ : December - 0,27; January- 0,25 ; February- 0,34

A special role in the acclimation of plants to low temperatures is assigned to strengthening the functioning of the antioxidant protection system, because under stressful effects active oxygen species are formed, leading to the growth of redox reactions in the plant cell [13]. Both antioxidant enzymes (peroxidases, etc.) and low-molecular-weight compounds (proline, 
ascorbic acid, phenolic compounds) take part in functioning of antioxidant protective system under abiotic stressful conditions [11].

According to many authors, peroxidase can serve as a protein marker for assessing the degree of plant resistance to stress factors.

We found that a large activity of peroxidase in the vine (0.11- $0.18 \mathrm{sec}^{-1} / \mathrm{g}$ of raw weight) was noted in the varieties 'Kristal', 'Krasnostop AZOS', 'Dostoyniy' and 'Vostorg'.

Low-molecular-weight compounds such as proline, known not only as an osmoprotector, but also as a scavenger of reactive oxygen intermediate accumulating under stress to neutralize ROS, can replenish the insufficient activity of enzyme protection systems [14].

Proline accumulated in larger quantities In the buds of grape varieties 'Zarif' and 'Aligote' than in other studied varieties (Fig. 4). Probably, protective properties in the studied grape varieties are exhibited in maintaining a balance between the activity of peroxidase and the accumulation of proline during the winter, which ensures the normal passage of wintering processes.

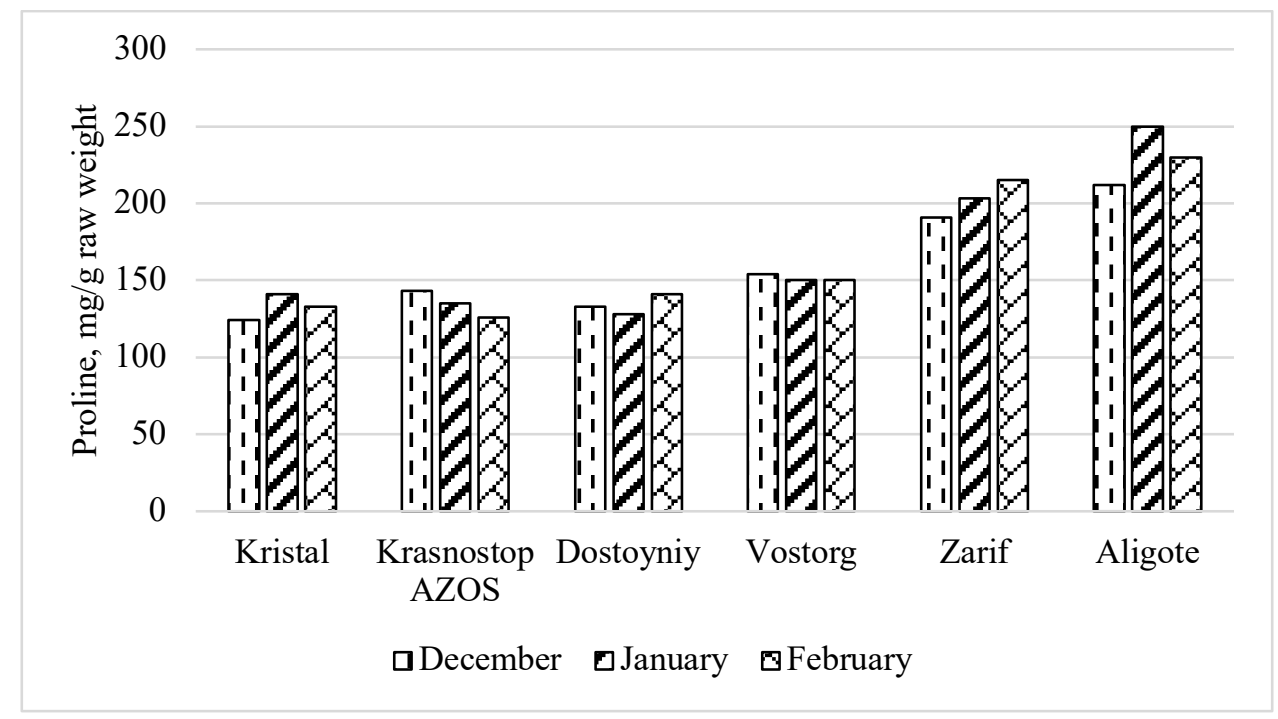

Fig. 4. Dynamic of proline contained in grape buds in winter season 2017-2019 (average value) $\mathrm{LSD}_{0,5}$ : December - 0,16; January- 0,85; February- 0,13

According to some authors, ascorbic acid, which is another metabolite of the antioxidant protection system, is also an indirect indicator of plant frost resistance. The protective properties of ascorbic acid are exhibited in inhibiting the flow of water, reducing the water content, changing the mobility of intracellular water. Increased content of ascorbic acid in winter can serve as an indicator of resistance of plants to low temperatures, winterhardiness varieties accumulated more ascorbic acid than less winterhardiness ones [15].

As seen in Fig. 5 the content of ascorbic acid in the buds of the studied grape varieties ranges from 5 ('Aligote') to $45 \mu \mathrm{g} / \mathrm{g}$ ('Dostoyniy', 'Krasnostop AZOS') of raw weight. 


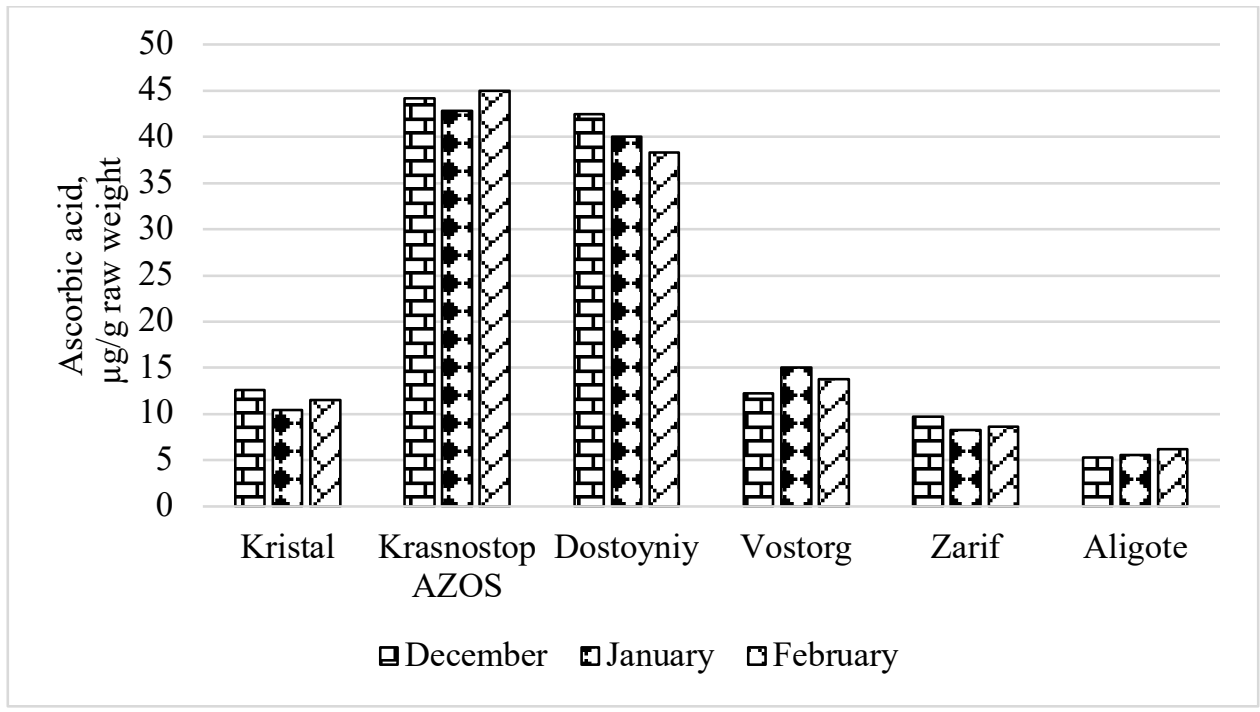

Fig. 5. Ascorbic acid contained in grape buds in winter season 2017-2019 (average value) $\operatorname{LSD}_{0,5}$ : December - 0,15; January- 0,44; February- 0,25

\section{Conclusion}

According to physiological-biochemical research results more winterhardiness were varieties 'Krasnostop AZOS', 'Dostoyniy', 'Kristal' than varieties 'Aligote', 'Vostorg', 'Zarif' in conditions of climate change in Anapa-Taman region of Russia and they could be sources of economically valuable trait for breeding - frost resistance.

\section{References}

1. J. Cragin, M. Serpe, M. Keller, K. Shellie, Am J Enol Vitic, 68 (2), 195-202 (2017) https://doi.org/10.5344/ajev.2016.16078

2. L.V. Gusta, M. Wisniewski, Physiologia Plantarum, 147 (1), 4-14 (2013) https://doi.org/10.1111/j.1399-3054.2012.01611.x

3. Y. Zhao, Z.-X. Wang, Yi-M. Yang, Hai-S. Liu, G.L. Shi, J. Ai, Sci. Hort., 259, 108760 (2020) https://doi.org/10.1016/j.scienta.2019.108760

4. J.C. Ferguson, M.M. Moyer, L.J. Mills, G. Hoogenboom, M. Keller, Am J Enol Vitic, 65 (1), 59-71 (2014) https://doi.org/10.5344/ajev.2013.13098

5. M. Wisniewski, L. Gusta, G. Neuner, Environ. Exp. Bot., 99, 133-140 (2014) https://doi.org/10.1016/j.envexpbot.2013.11.011

6. N.I. Nenko, I.A. Ilina, G.K. Kiseleva, E.K. Yablonskay, Acad. J. Food Res., 7(1), 001011 (2019) DOI:10.15413/ajfr.2018.0105 https://www.academiapublishing.org/journal s/ajfr/abstract/2019/Jan/Nenko\%20et\%20al.htm

7. N.I. Nenko, I.A. Ilina, G.K. Kiseleva, E.K. Yablonskay, Proceedings of the Latvian Academy of Sciences, 73(1), 56-65 (2019) https://doi.org/10.2478/prolas-2018-0046

8. F. Gonzalez Antivilo, R. C. Paz, M. Echeverria, M. Keller, J. Tognetti, R. Borgo, F.R. Juñent, Agric. For. Meteorol., 262, 227-236 (2018) https://doi.org/10.1016/j.agrformet.2018.07.017

9. B.-H. Chen, B. Zhang, J. Mao, Y. Hao, R. Yang, X.-H. Cai, S.-Y. Qi, Plant Physiology Journal, 50 (4), 535-541 (2014) DOI: 10.13592/j.cnki.ppj.2013.0441 
https://www.scopus.com/record/display.uri?eid=2-s2.0-84902207820\&origin=inward \&txGid=c91990ee98992d95337176f17f40ce99

10. M. Keller, The science of grapevines, 267-341 (2015) https://doi.org/10.1016/B978-012-419987-3.00007-8

11. V. Zufferey, F. Murisier, P. Vivin, S. Belcher, F. Lorenzini, J. L. Spring, O. Viret, Vitis, 51(3), 103-110 (2012) https://doi.org/10.5073/vitis.2012.51.103-110

12. J. Samoticha, A. Wojdyło, T. Golis, Food Chem., 215, 263273 (2017) https://doi.org/10.1016/j.foodchem.2016.07.147

13. J. Mulero, F. Pardo, P Zafrilla, J. Food Compos. Anal., 23 (6), 569-574 (2010) https://doi.org/10.1016/j.jfca.2010.05.001

14. R. Arora, L.J. Rowland, HortScience, 46 (8), 10701078 (2011) https://doi.org/10.21273/HORTSCI.46.8.1070

15. M.A. Hossain, M.A. Hoque, D.J. Burritt, F. Masayuki, Oxidative Damage to Plant: Antioxidant Networks and Signaling.s (Elsevier Inc., 477-522, 2014) https://doi.org/10.1016/B978-0-12-799963-0.00016-2

16. J. Zhang, X. Wu, R. Niu, Y. Liu, N. Liu, W. Xu, Y. Wang, Vitis, 51 (4), 153-160 (2012) https://doi.org/10.5073/vitis.2012.51.153-160 